\title{
ANALISIS KEMAMPUAN MENERAPKAN STRATEGI PEMECAHAN MASALAHDITINJAU DARI PERSPEKTIF METAKOGNITIF
}

\author{
Uus Kusdinar \\ Pendidikan Matematika Universitas Ahmad Dahlan \\ kusdinar@uad.ac.id
}

\begin{abstract}
ABSTRAK
Kemampuan pemecahan masalah merupakan bagian yang sangat pentingdalam pembelajaran matematika. Oleh karena itu mahasiswa program studi pendidikan matematika sebagai calon guru bidang matematika harus menguasai strategi pemecahan masalah dan penerapannya dalam pembelajaran. Tujuan penelitian ini adalah untuk mengetahui perilaku metakognitif mahasiswa program studi pendidikan matematika Universitas Ahmad Dahlan (UAD) di dalam menerapkan strategi pemecahan masalah matematika melalui penggunaan instrumen monitoring diri metakognisi. Subjek penelitiannya adalah mahasiswa semester III program studi pendidikan matematika UAD. Teknik pengumpulan data dengan observasi dan angket. Pengolahan data yang digunakan dengan cara analisis deskriftif kualitatif. Hasil penelitian menunjukkan bahwa kemampuan mahasiswa di dalam menerapkan strategi pemecahan masalah belum sesuai harapan, mahasiswa masih kesulitan menerapkan langkah-langkah penyelesaian secara prosedural yang sesuai dengan strategi pemecahan masalah. Penggunaan instrumen monitoring diri metakognisi menunjukkan peningkatan hasil yang positif di dalam menerapkan strategi pemecahan masalah.
\end{abstract}

Kata kunci : pemecahan masalah, instrumen monitoring diri, metakognitif

\begin{abstract}
Problem solving ability is a very important part in the learning of mathematics. Therefore student of mathematics education as a mathematics teacher candidates must master problemsolving strategies and their application in learning. The purpose of this study is to investigate the metacognitive behavior of students of mathematics education University of Ahmad Dahlan (UAD) in applying mathematical problem solving strategies through the use of self-monitoring instrument metacognition. Subject of research is the third semester students of mathematics education courses UAD. The technique of collecting data through observation and questionnaires. Processing of the data used by means of a qualitative descriptive analysis. The results showed that the ability of students to apply problem-solving strategies not as expected, the students still have difficulty implementing measures procedurally appropriate settlement with the problem-solving strategies. The use of self-monitoring instrument metacognition showed increased positive results in applying problem-solving strategies.
\end{abstract}

Keywords:problem solving,self-monitoring instrument, metacognitive

\section{Pendahuluan}

Proses berpikir dalam pemecahan masalah merupakan hal penting yang perlu mendapat perhatian pendidik terutama untuk membantu peserta didik agar dapat mengembangkan kemampuannya memecahkan masalah baik dalam konteks dunia nyata maupun 
dalam konteks matematika. Tujuan utama mengajarkan pemecahan masalah dalam matematika adalah tidak hanya untuk melengkapi peserta didik dengan sekumpulan keterampilan atau proses, tetapi lebih kepada memungkinkan peserta didik berpikir untuk dirinya sendiri.

Berpikir untuk dirinya sendiri berkaitan dengan kesadaran siswa terhadap kemampuannya untuk mengembangkan berbagai cara yang mungkin ditempuh dalam memecahkan masalah. Proses menyadari dan mengatur berpikir sendiri tersebut, dikenal sebagai metakognisi, termasuk didalamnya adalah berpikir tentang bagaimana membuat pendekatan terhadap masalah, memilih strategi yang digunakan untuk menemukan pemecahan, dan bertanya kepada diri sendiri tentang masalah tersebut.

Pemecahan masalah yang efektif dapat diperoleh dengan memberi kesempatan kepada peserta didik untuk menerapkan strategi metakognitif ketika menyelesaikan soal (mcloughlin dan hollingworth, 2003). Terlaksananya proses metakognitif dalam pemecahan masalah merupakan salah satu faktor menarik yang banyak diperhatikan oleh kalangan peneliti pendidikan. Hal tersebut disebabkan keuntungan yang dapat diperoleh ketika pemecahan masalah dilakukan dengan melibatkan kesadaran terhadap proses berpikir serta kemampuan pengaturan diri, sehingga memungkinkan terbangunnya pemahaman yang kuat dan menyeluruh terhadap masalah disertai alasan yang logis. Pemahaman semacam ini merupakan sesuatu yang selalu ditekankan ketika berlangsung pembelajaran matematika di semua tingkatan pendidikan, karena kesesuaiannya yang kuat dengan pola berpikir matematika.

Kemampuan memecahkan masalah adalah salah satu pendekatan pembelajaran yang dikembangkan pada mata pelajaran matematika baik pada kurikulum 2013 atau kurikulumkurikulum sebelumnya. Pemecahan masalah adalah kemampuan kognitif tingkat tinggi.

Mahasiswa lptk yang akan menjadi guru memerlukan pemahaman tentang strategi pembelajaran matematika dengan menggunakan pendekatan pemecahan masalah.

Kebutuhan ini juga ditekankan kepada mahasiswa program studi pendidikan matematika yang diharapkan dapat menerapkan pendekatan pembelajaran pemecahan masalah di sekolah nantinya. Mahasiswa program studi pendidikan matematika perlu diberikan pembekalan tentang pemecahan 
masalah meliputi model, pendekatan, strategi, dan metode pembelajaran

Menurut lester (dalam goos \& galbraith, 2000:1), salah satu kajian yang menarik tentang pemecahan masalah adalah peran metakognisi dalam pemecahan masalah. Untuk mengetahui metakognisi mahasiswa saat melakukan pemecahan masalah matematika dapat digunakan instrumen monitoring diri metakognisi berbentuk angket. Angket diberikan sesaat setelah mahasiswa menyelesaikan soal pemecahan masalah. Dengan angket ini, dapat diketahui aktivitas metakognisi mahasiswa ketika memecahkan masalah matematika serta kekuarangan dan kesalahan mahasiswa dalam menggunakan strategi pemecahan masalah. Setelah itu, kemampuan mahasiswa menggunakan strategi pemecahan masalah dapat diperbaiki.

Berdasarkan hal tersebut, maka dilakukan penelitian tindakan kelas (ptk) untuk meningkatkan kemampuan mahasiswa menerapkan strategi pemecahan masalah matematika melalui penggunaan instrumen monitoring diri metakognisi.

Permasalahan lebih lanjut dirumuskan sebagai berikut : bagaimanakah membuat dan menggunakan instrumen monitoring diri metakognisi dalam pembelajaran matematika agar dapat meningkatkan kemampuan mahasiswa menerapkan strategi pemecahan masalah matematika ? Tujuan penelitian ini adalah untuk mengetahui perilaku metakognitif mahasiswa program studi pendidikan matematika universitas ahmad dahlan (uad) di dalam menerapkan strategi pemecahan masalah matematika melalui penggunaan instrumen monitoring diri metakognisi.

\section{Tinjauan Pustaka}

\section{Masalah Matematika}

Suatu masalah biasanya memuat situasi yang mendorong seseorang untuk menyelesaikannya tetapi tidak tahu secara langsung apa yang harus dilakukan untuk menyelesaikannya. Jika suatu masalah diberikan kepada seorang siswa dan siswa tersebut dapat mengetahui cara penyelesainnya dengan benar, maka soal tersebut tidak dapat dikatakan sebagai masalah. Jadi, sesuatu dianggap masalah bergantung kepada orang yang menghadapi masalah tersebut walaupun suatu soal tetap dapat memiliki karakteristik tertentu sebagai masalah.

Moursund (2005:29) mengatakan bahwa seseorang dianggap memiliki dan menghadapi masalah bila menghadapi 4 situasi berikut, yaitu : memahami dengan jelas kondisi atau situasi yang sedang terjadi; memahami dengan jelas tujuan yang diharapkan; memahami sumber 
daya yang dapat dimanfaatkan untuk mengatasi situasi yang terjadi sesuai dengan tujuan yang diinginkan; serta memiliki kemampuan menggunakan berbagai sumber daya untuk mencapai tujuan. Dalam pembelajaran matematika, masalah dapat disajikan dalam bentuk soal tidak rutin : soal cerita, penggambaran penomena atau kejadian, ilustrasi gambar, atau teka-teki. Masalah tersebut kemudian disebut masalah matematika karena mengandung konsep matematika.

\section{Metakognisi dalam Pemecahan}

\section{Masalah Matematika}

Menurut Goos\& Galbraith (2000:2), cara berpikir secara matematis yang efektif dalam memecahkan masalah meliputi tidak saja aktivitas kognitif, seperti menyajikan dan menyelesaikan tugas serta menerapkan strategi untuk menemukan solusi, tetapi juga meliputi pengamatan metakognisi untuk mengatur berbagai aktivitas serta untuk membuat keputusan sesuai dengan kemampuan kognitifnya.Polya (Suherman et.al., 2001:84),mengatakan bahwa solusi soal pemecahan masalah memuat empat langkah penyelesaian, yaitu : pemahaman terhadap permasalahan; perencanaan penyelesaian masalah; melaksanakan perencanaan penyelesaian masalah; dan memeriksa kembali penyelesaian., sedangkan menurut Schoenfeld (Goos et.al., 2000:2) terdapat 5 tahap pemecahan masalah, yaitu : Reading, Analisys, Exploration, Planning/ Implementation, dan Verification. Artzt \& Armour-Thomas (Goos et.al, 2000:2) telah mengembangkan langkah-langkah pemecahan masalah dari Schoenfeld, yaitu menjadi Reading, Understanding, Analisys, Exploration, Planning, Implementation, dan Verification. Langkah-langkah penyelesaian masalah tersebut merupakan pengembangan dari 4 langkah Polya.

Menurut Suherman et.al. (2001 : 95), metakognitif adalah suatu kata yang berkaitan dengan apa yang diketahui tentang dirinya sebagai individu yang belajar dan bagaimana dia mengontrol serta menyesuaikan prilakunya. Seseorang perlu menyadari kekurangan dan kelebihan yang dimilikinya. Metakognitif adalah suatu bentuk kemampuan untuk melihat pada diri sendiri sehingga apa yang dia lakukan dapat terkontrol secara optimal. Dengan kemampuan seperti ini seseorang dimungkinkan memiliki kemampuan tinggi dalam memecahkan masalah, sebab dalam setiap langkah yang dia kerjakan senantiasa muncul pertanyaan : “Apa yang saya kerjakan ?”; "Mengapa saya mengerjakan ini?”; "Hal apa yang membantu saya untuk menyelesaikan 
masalah ini?". Sementara menurut Margaret W. Matlin (2009) metakognitif adalah "knowledge and awareness about cognitive processes - or our thought about thinking".

Kuhn mendefinisikan metakognisi sebagai kesadaran dan pengelolaan proses kognitif dan produk yang dimiliki oleh seseorang (Kuhn, 2000). Sementara Schneider \& Lockl (dalam Artikasari, 2011) mendefinisikan metakognisi sebagai pengetahuan atau kegiatan yang mengatur kognisi. Konsep ini secara luas meliputi pengetahuan individu tentang keberadaan dasarnya sebagai individu yang memiliki kemampuan mengenali, pengetahuan tentang tugas-tugas dasar kognitif yang berbeda dan pengetahuan tentang strategi yang memungkinkan untuk tugas yang berbeda baru. Dengan demikian, orang tidak hanya berpikir tentang obyek dan perilaku, tetapi juga pada kognisi itu sendiri.Hal ini menunjukkan bahwa metakognisi mencakup seseorang berpikir (Kuhn \& Dean, 2003; Artikasari, 2011).

Kesuksesan seseorang dalam memecahkan masalah antara lain sangat bergantung pada kesadarannya tentang apa yang mereka ketahui dan bagaimana dia melakukannya. Menurut Suherman et.al. (2001:95), metakognisi adalah suatu kata yang berkaitan dengan apa yang diketahui tentang dirinya sebagai individu yang belajar dan bagaimana dia mengontrol serta menyesuaikan prilakunya.

\section{Instrumen Monitoring Diri Metakognisi}

Intrumen ini dirancang berupa angket untuk mengetahui strategi metakognisi mahasiswa dalam memecahkan masalah matematika. Instrumen ini dikembangkan berdasarkan instrumen yang digunakan oleh Goos et.al. (2000:18). Instrumen tersebut dibagi menjadi 4 bagian, yaitu untuk mengetahui strategi metakognisi mahasiswa : (1) dalam proses memahami masalah; di saat memecahkan masalah; (2) ketika selesai memecahkan masalah; (3) dan dalam memilih strategi yang digunakan oleh mahasiswa. Berikut ini adalah pertanyaan-pertanyaan metakognisi dalam Instrumen Monitoring Diri Metakognisi.

Tabel 1.Instrumen Monitoring Diri Metakognisi

\begin{tabular}{ll}
\hline \multicolumn{1}{c}{ Pertanyaan-pertanyaan Monitoring Diri } & \multicolumn{1}{c}{ Tujuan Pertanyaan } \\
\hline Sebelum memulai memecahkan masalah & Menilai pengetahuan pada masalah \\
1. Saya membaca masalah lebih dari satu kali. & Menilai pemahaman terhadap masalah \\
2. Saya yakin bahwa saya memahami masalah yang & \\
$\quad \begin{array}{l}\text { ditanyakan pada saya. } \\
\text { 3. Saya mencoba menyajikan masalah dengan bahasa saya }\end{array}$ & Menilai pemahaman terhadap masalah \\
4. Saydiri. &
\end{tabular}


menyelesaikan masalah ang mirip dengan masalah ini.

terhadap masalah

5. Saya mengidentifikasi dan memeriksa setiap informasi yang terdapat dalam masalah ini.

Menilai pengetahuan dan pemahaman

terhadap masalah

6. Saya berpikir tentang pendekatan yang berbeda yang akan saya coba untuk memecahkan masalah.

Menilai tentang pemilihan strategi

pe.mecahan masalah

Ketika menyelesaikan masalah

7. Saya melakukan pemecahan masalah tahap per tahap

8. Saya telah membuat kesalahan dan mengulangi beberapa pekerjaan

9. Saya membaca ulang masalah untuk memeriksa bahwa saya telah melakukan langkah yang tepat.

10. Saya bertanya pada diri sendiri apakah saya sudah mendekati penyelesaian.

11. Saya memikirkan ulang tentang metode penyelesaianyang saya gunakan dan mencoba metode/ pendekatan baru

Setelah menyelesaikan masalah

12. Saya memeriksa hasil perhitungan agar yakin bahwa penyelesaiannya sudah benar.

Menilai penerapan strategi pemecahan

masalah

Menilai pemeriksaan pada kesalahan

Menilai pemahaman pada masalah

Menilai pemahaman pada progress

penyelesaian

Menilai penerapan strategi yang beragam

Menilai akurasi dan ketepatan penyelesaian Menilai penerapan strategi

13. Saya memeriksa kembali metode yang digunakan untuk mengetahui bahwa saya telah menyelesaikan masalah seperti dimaksud '

\section{Menilai ketepatan dari solusi}

14. Saya bertanya pada diri sendiri apakah jawabannya sudah benar atau tidak .

15. Saya memikirkan tentang cara lain untuk menyelesaikan masalah.

Strategi yang digunakan

16. Saya menggunakan metode Guess and Che

17. Saya menggunakan aljabar untuk merancang beberapa persamaan untuk diselesaikan

18. Saya membuat diagram atau gambar.

19. Saya menuliskan hal-hal yang penting.

20. Saya merasa bingung dan tidak bisa memutuskan untuk berbuat sesuatu

21. Saya menggunakan cara lain untuk untuk menyelesaikan masalah.

\section{Metodologi Penelitian}

Metode penelitian yang digunakan adalah Penelitian Tindakan Kelas (PTK) dengan jumlah 2 siklus. Subjek penelitian ini adalah mahasiswa semester III Program Studi Pendidikan Matematika FKIP Universitas Ahmad Dahlan tahun akademik 2015/2016. Dari 5 kelas yang tersedia dipilih kelas 3E yang berjumlah 25 orang. Mahasiswa tersebut sedang mengambil matakuliah Aljabar Linier. Materi yang dijadikan soal/masalah adalah konsep vektor dan ruang vektor.

PTK ini dilaksanakan dengan langkah-langkah meliputi : tahap refleksi awal; merancang langkah-langkah tindakan; membuat Satuan Acara Perkuliahan (SAP) dan instrumeninstrumen penelitian; serta tahap pelaksanaan tindakan meliputi : tahap orientasi, tahap persiapan pra tindakan, tahap pelaksanaan tindakan, tahap 
pengamatan, tahap refleksi, dan tahap perencanaan tindakan lanjutan.

Pada penelitian ini dirancang beberapa instrumen, yaitu : Instrumen Monitoring Diri Metakognisi, instrumen observasi perencanaan pembelajaran, instrumen observasi proses pembelajaran dan instrumen data pendukung dan penghambat dalam pembelajaran. Pada Siklus I mahasiswa diberikan Lembar Kerja tentang Vektor dan operasinya. Sedangkan pada Siklus II masalahnya adalah masalah ruang vektor serta membuat generalisasi dari masalah itu. Sesaat setelah mahasiswa selesai memecahkan masalah, kemudian mahasiswa mengisi angket Instrumen Monitoring Diri Metakognisi.

Teknik pengumpulan data yang digunakan dalam penelitian ini adalah sebagai berikut : teknik observasi, teknik tes atau penilaian dan analisis deskriptif. Teknik pengolahannya adalah metode coding atau labeling, triangulasi, dan saturasi.

\section{Hasil Penelitian dan Pembahasan}

Meskipun mahasiswa telah mempelajari strategi pemecahan masalah pada mata kuliah metode pembelajaran matematika, namun kemampuan mereka dalam menggunakan strategi pemecahan masalah matematika belum sesuai dengan harapan. Langkah-langkah yang digunakan mahasiswa belum sesuai dengan lanngkah-langkah strategi pemecahan masalah.

Pada pra penelitian, mahasiswa diberikan soal tidak rutin tentang konsep operasi penjumlahan vektor. Setelah mahasiswa menyelesaikan soal tersebut, mereka diberi angket Instrumen Monitoring Diri Metakognisi untuk mengetahui metakognisi mahasiswa ketika memecahkan masalah tersebut. Kesimpulannya, hanya ada $12 \%$ mahasiswa yang menyelesaikan soal dengan benar dengan strategi yang tepat.

\section{Persiapan}

Bahan pembelajaran yang disiapkan meliputi materi tentang strategi pemecahan masalah serta pemilihan soal/masalah untuk diberikan kepada mahasiswa dalam bentuk lembar kerja. .Pemilihan materi sudah tepat karena sesuai dengan materi yang sedang dibahas pada perkuliahan rutin yaitu konsep vektor dan ruang vektor. Soal pada lembar kerja di Siklus I dan Siklus II secara konseptual berhubungan sehingga mahasiswa dapat melakukan perbaikan strategi yang digunakan ketika memecahkan masalah.

Skenario pembelajaran disusun dalam waktu 2 jam. Langkah-langkah pembelajarannya dirancang sebagai berikut : 
1. Tahap apersepsi. Dosen (peneliti)

dan mahasiswa melakukan tanya jawab tentang konsep strategi pemecahan masalah

2. Tahap eksplorasi. Dosen menjelaskan tentang pentingnya pemecahan masalah; dosen menjelaskan strategi-strategi pemecahan masalah; dosen menjelaskan hasil evaluasi terhadap kemampuan mahasiswa dalam memecahkan masalah pada kegiatan pra tindakan; dan dosen menjelasken pentingnya strategi berpikir (metakognisi) dalam memecahkan masalah

3. Tahap Konsolidasi. Dosen memberikan lembar kerja yang memuat soal untuk diselesaikan dengan strategi pemecahan masalah; mahasiswa menyelesaikan soal secara individu; dan dosen menjawab pertanyaan-pertanyaan mahasiswa berkenaan dengan kesulitan yang mereka hadapi

4. Tahap pembentukan sikap. Dosen membahas beberapa hasil perkerjaan mahasiswa dan menjelaskan pola umum dan kecenderungan mahasiswa dalam menyelesaiakan soal; dosen memberikan Instrumen Monitoring Diri Metakognisi kepada mahasiswa untuk diisi; dan dosen memandu untuk mengisinya terutama jika terdapat mahasiswa yang belum paham dengan pertanyaan-pertanyaannya

\section{Hasil Pelaksanaan}

Proses pembelajaran pada Siklus I dan Siklus II pada dasarnya berjalan sesuai dengan kebutuhan. Mahasiswa terlihat aktif dalam mengerjakan lembar kerja. Sesuai rencana, tidak dilakukan tes formatif tetapi penilaian kemampuan mahasiswa tetap bisa dilakukan melalui Instrumen Monitoring Diri Metakognisi dan Lembar Jawaban mahasiswa. Pelaksanaan pembelajaran Siklus I dan Siklus II tidak jauh berbeda hanya saja pada Siklus II mahasiswa ditekankan agar dapat menemukan pola umum pemecahan soal.

Hasil pembelajaran pada Siklus I dan Siklus II menunjukkan peningkatan kemampuan mahasiswa dalam menerapkan strategi pemecahan masalah matematika. Hal ini dapat dilihat pada tabel berikut ini.

Tabel 2. Kemampuan Mahasiswa MenerapkanStrategi Pemecahan Masalah

\begin{tabular}{cccccc}
\hline $\begin{array}{c}\text { Pertan } \\
\text { yaan } \\
\text { ke- }\end{array}$ & $\begin{array}{c}\text { Jawa } \\
\text { ban } \\
\text { "Ya" }\end{array}$ & $\begin{array}{c}\text { Peruba } \\
\text { han \% }\end{array}$ & & & \\
\hline & $\begin{array}{c}\text { Siklu } \\
\text { s I }\end{array}$ & $\begin{array}{c}\text { Siklus } \\
\text { II }\end{array}$ & & & \\
& $\sum$ & $\%$ & $\sum$ & $\%$ & \\
& 20 & 80 & 23 & 92 & 12 \\
$\mathbf{1}$ & 18 & 72 & 22 & 88 & 16 \\
$\mathbf{2}$ & 20 & 80 & 23 & 92 & 12 \\
$\mathbf{3}$ & 15 & 60 & 18 & 72 & 12 \\
$\mathbf{4}$ & 18 & 72 & 20 & 80 & 8 \\
$\mathbf{5}$ & 14 & 56 & 18 & 72 & 16 \\
\hline $\mathbf{6}$ & & & & & \\
\hline
\end{tabular}




\begin{tabular}{cccccc}
\hline $\mathbf{7}$ & 18 & 72 & 21 & 84 & 12 \\
$\mathbf{8}$ & 20 & 80 & 18 & 72 & -8 \\
$\mathbf{9}$ & 22 & 88 & 24 & 96 & 8 \\
$\mathbf{1 0}$ & 17 & 68 & 22 & 88 & 20 \\
$\mathbf{1 1}$ & 18 & 72 & 20 & 80 & 8 \\
$\mathbf{1 2}$ & 12 & 48 & 20 & 80 & 32 \\
$\mathbf{1 3}$ & 16 & 64 & 18 & 72 & 8 \\
$\mathbf{1 4}$ & 19 & 76 & 22 & 88 & 12 \\
$\mathbf{1 5}$ & 16 & 64 & 19 & 76 & 12 \\
\hline
\end{tabular}

Berdasarkan Tabel 2 di atas, secara umum terjadi peningkatan kemampuan mahasiswa menerapkan strategi pemecahan masalah. Pada langkah memahami masalah, semua jawaban pertanyaan mengalami kenaikan.

Hal ini berarti bahwa kebanyakan mahasiswa memikirkan pendekatan yang berbeda dalam memahami dan memecahkan masalah. Hal ini disebabkan soal yang diberikan pada siklus II memberikan keleluasaan kepada mahasiswa untuk menggunakan strategi yang berbeda pada penyelesaian masalah.

Penurunan pada pertanyaan ke-8 berarti beberapa mahasiswa merasa tidak melakukan kesalahan lagi dan berusaha memperbaiki pekerjaannya. Pertanyaan ini ingin melihat bagaimana mahasiswa mampu memperbaiki kesalahan yang mereka lakukan ketika memecahkan masalah.

Kenaikan terbesar terjadi pada pertanyaan ke-13, hal ini menandakan bahwa sebagian besar mahasiswa mencoba untuk melihat kembali metode atau strategi yang digunakan pada pemecahan masalah.

Tabel 3. Strategi Pemecahan Masalah yang Digunakan Mahasiswa

\begin{tabular}{lcccc}
\hline Jenis Strategi & $\begin{array}{c}\text { Siklus } \\
\text { I }\end{array}$ & $\begin{array}{c}\text { Siklus } \\
\text { II }\end{array}$ & & \\
\hline $\begin{array}{l}\text { Membuat } \\
\text { ilustrasi } \\
\text { gambar }\end{array}$ & 18 & 72 & 23 & 92 \\
$\begin{array}{l}\text { Menghitung } \\
\text { bagian per } \\
\text { bagian }\end{array}$ & 22 & 88 & 20 & 80 \\
$\begin{array}{l}\text { Menggunakan } \\
\text { contoh yang } \\
\text { sudah ada }\end{array}$ & 20 & 80 & 22 & 88 \\
$\begin{array}{l}\text { Menemukan } \\
\text { cara sendiri }\end{array}$ & 0 & 0 & 4 & 16 \\
\hline
\end{tabular}

Pada Siklus I sebagian besar mahasiswa menggunakan bantuan ilustrasi gambar dalam penyelesaian masalah vektor, dan terjadi peningkatan pada siklus II. Sebenarnya, ketika dosen memantau aktivitas mahasiswa, terlihat sebagian besar diantara mereka menggambar atau membuat ilustrasi tetapi tidak dituangkan pada lembar jawaban. Pada Siklus II sebagian besar (92\%) mahasiswa menggunakan ilustrasi gambar, dan menuangkannya dalam lembar jawaban.

Mahasiswa masih terbiasa dan sangat tergantung kepada contoh yang pernah dilakukan. Namun ada sebagian mahasiswa yang sudah mampu menemukan cara sendiri dalam menyelesaikan masalah.

Adanya perubahan strategi dalam penyelesaian masalah diduga dikarenakan 
adanya penggunaan instrument monitoring diri metakognisi. Hal ini diduga karena mahasiswa menjadi termotivasi untuk melakukan evaluasi diri di dalam menerapkan strategi pemecahan masalah.

\section{Kesimpulan dan Saran}

Kesimpulan

Berdasarkan hasil penelitian, kemampuan mahasiswa menerapkan strategi pemecahan masalah mengalami peningkatan untuk setiap langkahlangkah pemecahan masalah : memahami masalah, merancang strategi, menerapkan strategi dan memeriksa hasil. Sedangkan berdasarkan hasil pekerjaan lembar kerja, sebagian besar mahasiswa menjawab soal dengan lebih baik dan benar.

$$
\text { Pembelajaran menggunakan }
$$
instrumen monitoring diri metakognisi memberikan pengalaman dan dampak positif bagi mahasiswa terutama dalam menerapkan strategi pemecahan masalah. Saran

Dosen matematika perlu meningkatkan latihan kepada mahasiswa dalam menerapkan strategi pemecahan masalah. Begitu pula bagi mahasiswa sebagai calon guru matematika, perlu dilatih untuk merancang pembelajaran menggunakan pendekatan pemecahan masalah.
Instrumen monitoring diri metakognisi dapat dikembangkan dengan menguraikan lebih rinci pertanyaanpertanyaan metakognisinya.

\section{Pustaka}

Amin, I. and Sukestiyarno, Y.L.2015.Analysis Metacognitive SkillsOn Learning Mathematics In High School. International Journal of Education and Research Vol. 3 No. 3 March 2015.p. $213-222$.

Astikasari, H.S.M. 2011. Metakognisi Dan Theory Of Mind (Tom). Jurnal Psikologi Pitutur.Volume I, No 2, Juni 2011

Chairani, Z. 2013.Aktivitas Metakognisi Sebagai Salah Satu Alat Untuk Meningkatkan Kemampuan Siswa Dalam Pemecahan Masalah MatematikaKNPM V, Himpunan Matematika Indonesia, Juni 2013 Chick, N.L., Karis, T., \& Kernahan, C. 2009. Learning from Their Own Learning: HowMetacognitive and Meta-affective

ReflectionsEnhance Learning in Race-Related Courses . International Journal for the Scholarship ofTeaching and Learning (IJ-SoTL), Vol. 3 [2009], No. 1, Art. 16. 
Coutinho, S.A. 2007. The relationship between goals, metacognition, andacademic success. Educate Vol.7, No.1, 2007, pp. 39-47.

Du Toit, S.; Gary Kotze. 2009. Metacognitive Strategiesin the Teaching and Learning of Mathematics. Pythagoras, 70, 5767.

Du Toit,S \& Du Toit, G. 2013. Learner metacognition and mathematics achievement duringproblemsolving in a mathematics classroom. TD The Journal for Transdisciplinary Research in Southern Africa, 9(3), Special edition, December 2013, pp. 505518

Goos\& Gilbraith.(2000). A Money Problem 14 A Source of Insight Into Problem Solving Action. Queensland : The University of Queensland [online]. Diakses tanggal 14 Desember 2015 dari http://www.cimt. plymouth.ac.uk/jornal/pgmoney.p df

Händel,M., Artelt, C., \& Weinert, S. 2013. Assessing metacognitive knowledge:Development and evaluation of a test instrument. Journal for Educational Research
Online .Volume 5 (2013), No. 2, $162-188$

Iswahyudi， G. 2012. Aktivitas Metakognisi Dalam Memecahkan Masalah Pembuktian Langsung Ditinjau Dari Gender Dan Kemampuan Matematika. MakalahDisampaikan pada Seminar Nasional Program Studi Pendidikan Matematika UNS Surakarta 21 November 2012

Kuhn, D and Dean, D. 2003 Metacognition And Critical Thinking. Document Resume The Educational Resources Information Center (Eric) Pub Date 2003-04

Marsound, D. (2005). Improving Math Education in Elementary School : A Short Book for Teachers. Oregon : University of Oregon. [online]. http://darkwing.uoregon.edu/.../El Math.pdf

Matlin, M.W. 2009. Cognition (Seventh Edition). New York: John Wiley \& Sons, Inc.

Panaoura, A., Philippou, G. Christou, C. T.T. Young Pupils' Metacognitive Ability In MathematicsEuropean Research In Mathematics Education III 
Psychology. Vol 13, 2013, pp. 44-

Spray,E., Scevak, J. \&Cantwell, R. 2013. 57

Personal epistemological and metacognitive awareness 1 in first year preservice education students. Australian Journal of Educational \& Developmental

Suherman dkk .(2001). Strategi Pembelajaran Matematika Kontemporer. Bandung : Jurusan Pendidikan Matematika UPI. 